\begin{tabular}{|c|c|}
\hline 展 & 望 \\
\hline
\end{tabular}

\title{
19世紀じゅうたんの染料 一天然色素と合成染料一
}

\section{杉浦猛 雄}

\section{はじめに}

19 世紀後半合成染料加次々上世に出されるにつれ。 ヨーロッパは言うに及ばず，急速に世界各地へ，染織物 一般へ々広まっていった。その中でペルシャ，中央アジ ア等の能域へも交易商人等に上り速や加漫透されてい き，促来の天然色坔の代替品として奏際に使用される様 になったが、特に、とれら地域の特色あるじ沖うたんに どの様にその変遷が見られるかを知るととは美術工芸史 上興味あることである。そこで今四は先ずじゅうたんに ついて一般的なととを少しく述へた後で 15〜20世紀， 特に 19 世紀のじゅうたんに使用されている天然及び合 成染料の微量分析について，実例を上げてどの様に貝体 的に成され得るか説明する。乙の様な分析では如何に 簡果にかつ確実に分析するかが重要であり，之の過程で より多くのデータを集めながら，他の染織物への応用簕 井を应大するととが必要であるう。

美術工芸史上貴重な染織物に破損を与えずに，その染 織物に使用されている色素の同定が確寒に出来るならば 現在染織物に関して存在する多くの問題点が解决される 筈である。そのためには非破壊法が望ましいが，採集で きる試料量及びコストの点で非常に困難なため，染織物 より出来るだけ微量の試料を外形上の破損を与えずに採 集し，簡筆に色素同定されれば非常に有効である。従来 の色装分析法は 10 100 mg 上いった可成りの染色瀻維 量を必要とするか，使用色素の完全なる同定をせずに中 途半端の結論を出すかであった。例えば昆虫色素である Lac dye, Kermes, Cochinealの区别がなされかった り，アゾ染料にしてもただ笨にアソ化合物が使用されて いるとしどの特定のアゾ化合物かが決定されないまま済 まされてきた。そこでよりよい結果を得るため現代分析

Micro Scale Identification of Dyes in Rugs of the 19th Century

TAKEO SUGIURA

TOPPAN PRINTING Co., Ltd. Research Center 版印剧株式会社中央研究所主任研究貴 (Ph.D.
譏器の感度の利用及び相応の微量化学反応侸重点置い

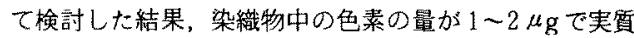
上簡単に同定可能な種々の実験結果を得たのでその一部 紹介する。

英語でrug上呼ばれる織物は床敷き，壁掛け，入り口 の吊し、テントバンド，小物入れ等を総称したあのであ る。その中であパイルのあるものを緞通と呼ぶが，ここ では便宜上一般に制染みの梁いじゅうたんと呼んで报う。 この種のじゅうたんの起源はトルキスタンの遊牧民に発 していると推察されるが，遺物は残っておらず，圐在の 所最古のじゅうたんは1949年ロシアのRudenkoにより 発煀された紀元前 5 世紀アルタイ地方 the Pazyryk Valleyの the Kurgan Vのbのよされている。じゅうたん の洒值は織り方，デザィン．配色の全体的バランスで決 まる。この内の織り方については，大多数のじゅうたん がパイルの結び目の種類により the Ghiordes (Turkish) と the Sehna (Persian) に分けられる。Sehnaは密で故
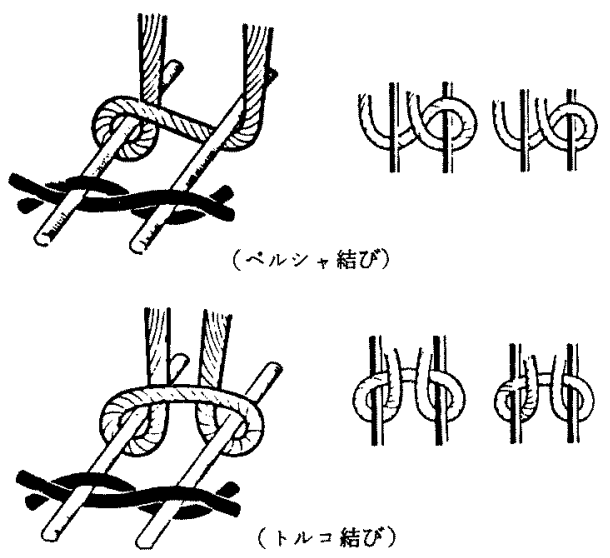

図 1 パイルの代表的結び目の種類

に柄もはっきりしており，Turkoman, China, Persiaの 一部, Ghiodesは粗く, Asia Minor, Caucasia, Persia 大部分，Indiaの一部の製品に多く，細かいあのは 100 , 粗いものは $10 \mathrm{knots} / \mathrm{cm}^{2}$ 位である。結び目が細かいか 
粗いかは製品の襄加ら眺める上よく分かり，系む細くて 強いもの，太くて弱いもの，撚系等があり，wool, cotton, jute 等の他天然に着色しているもの使狆てい る。次侄色の素になる色素であるが，織り方がそうで ある様に，染め方や色素の種類む，特定地域独特のものも ある一方で他地方との交易による接触等で入手され一地 万のみで使用されない色素も非常に多く存在する。天然 色素としては原則的に，blueは Indigo (genus Indigofera, 東インド原産)， red としては Madders (Rubiatinctorum, -munjista, -japonica 等)と尼虫色素とがあ bo

Madderは茜と䚿されるが，座地により又採菒樹命， 土地質，乾燥及び抽出条件により色の主組成物又はその 比が变化する。主成分としてはalizarinや purpurin 等で ある。

展虫色素としては Cochineal (Dactylopius coccus Costa; 主成分 carminic acid), Lac dye (Laccifer lacca kerr; laccaic acid), Kermes(Kermococcus ilicis L.; kermesic acid) 加普通に使用されている。Kermes はAfrica, Asia Minor, Greeceで古くから使われていた が，スペイン人による Mexico征服により1550年以後 多量の Cochineal が欧州に導入される様になっていた。 一方 Bengal, Siam， その他のアジア諸国で産していた Lac dyeは18世紀末に欧州に輸入され，合成染料加現 われる迄使用されていた。他にあまりよく知られていな いものにPolish Cochineal があり，東欧に産し carminic acid と kermesic acid が入っている。これら尾虫色素 は分光曲楾では工夫老施さないと全く区別されない。 yellows としてはその地力独自の植物の花，実，葉，

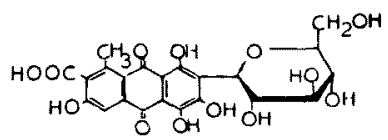

carminic acid $\left(\mathrm{C}_{22} \mathrm{H}_{20} \mathrm{O}_{13}\right)$
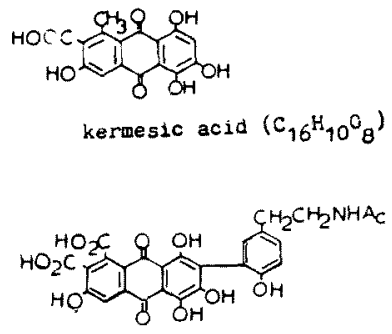

laccaic acid $A\left(A_{1}\right)\left(C_{26}{ }^{\mathrm{H}_{1}}{ }^{\mathrm{NO}}{ }_{12}\right)$

国2 red 系天然色害中の主成分
萃等より抽出して使用した場合が多い。そのため色具自 身の分析加出来ても，今度は栕物上との色素についての 調査が必要亡なり，難しい点加多々ある。Weld（主色素 luteolin), Persian Berries(Rhamnetin, Rhamnazin), Quercitron (quercitrin), Safflower (carthamic acid), Saffron (crocetin)'等々あり,としでは flavonol 系の yellowsについて簡単に後述する。更に各地域のじゅう たんは特異な色合いを持っており，Persiaのblue，Turkoman $や$ Asia Minor $の$ red, China $の$ yellow があり. 又问じ色素からであ媒染剂の使い方，他色上の涺合の仕 方等により夫々の特徵を出している。

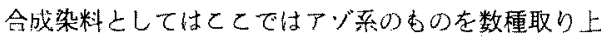
げる。

よく織られ染めが立派であっても，それら以上に重要 上言えるのがパターンとかデザインであり，それにより 織った人々の質実さ，宗教，神秘性を同い知ることが出 来，美的なものと同時汇民族独自の内的精神を汲子取る ことが出来る。デザインに蔦，集，花の流線を使うのは文 化レベルの高かったChina, India, Persia, Asia Minor の一部に，幾何学的模漛の繰り返しはTurkestan, Cau-

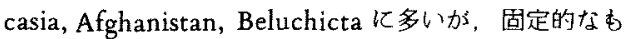
のではない。例えば流線は大多数のじゅうたんに多かれ 少なか力措かれている。上記の織り方，色，デザインで じゅうたんの美的歴史的評価を行なっているが，若して れに色素又は㵶維の分析が可能なら評価判断は上り一層 正確になる。以下に幾つかの色素についてパイル試料よ り同定する方法を説明する。一般に簡単な方法上しては 既知のもの及び解決済のデー夕を出来る丈多く持ち，そ の分析方法の内最も適した方法で同定すればよい。以下 に説明する内容は，1 つ0色素について多数の 方析方法を示しているが，これらが全てなりれ ば同定出来ないというのでなく，1〜2ケあれ ば実務的には充分である。他は参考データとし て見て頂きたい。試料からの色素の抽出は $\mathrm{MeOH}: 1.1 \mathrm{~N} \mathrm{HCl}=4 \sim 2: 10$ 溶液を用い た。必要に応じ pyridine 水溶液当使用した。

\section{1. 昆虫色素}

Prof. J. M. A. Thompson 所有の美しい Salor rugs より redの試料 12 件採集した。 中央アジアでの Turkoman遊牧民族の歴史は ここで扱うrugの製作年代と考えられる19世紀 前半においては外界には一般にほとんど知られ ていなかった。それでも遈しきは通商の道で， 物の出入れは可成りの量で行なわれていた。こ こにあげた Salor は Tekke, Saryg, Chodor, 
Yomud, Ersari 等の部族關にあって、15〜16 世紀カス ピ海東岸に勢力を誇った一部族であり，その後あ常に他 部族より一目置かれたものである。その織物である特徴 的な juval (Chuval, Choval 等とも書く; 物入れ) の深い $\operatorname{red} の$ 主柄 (Gul) は図 3 に示す様小小塔加向き合った所 に花柄が埋め込まれている。との redは多くの場合 $\mathrm{Co}^{-}$

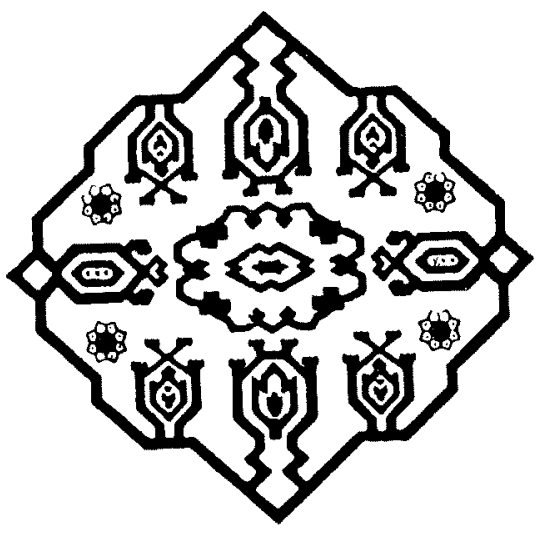

図 3 Salor Gulの一例

chineal であるが，一部に Lac dyeを使うことああり得 るので分析することとした。

先ず試料より色素を抽出し， $\mathrm{N}_{2}$ ガス下MeOHを蒸発 さ世，その残液に $9 \% \mathrm{H}_{2} \mathrm{SO}_{4} \mathrm{aq}$ ，次に $\mathrm{Et}_{2} \mathrm{O}$ 加え， 振壍後分離液の分光吸収曲線 (以下 uv/vis spec. 上略 す)をとり， $\lambda_{\max }$ におりる吸光係数の值を比較する $\left(\mathrm{E}_{\mathrm{Et}_{2} \mathrm{O}} / \mathrm{E}_{\mathrm{aq}}\right.$ )（図4)試料について標準品之較へ次面 表 2 より約 0.5 を示す 2 例がLac dyeで，他は約 0.1 を 示し Cochinealと分り，この地方であLac dye 使用し ていた証である。又上の二層液より $\mathrm{Et}_{2} \mathrm{O}$ 蒸発させた
残液を 70 80\% $\mathrm{H}_{2} \mathrm{SO}$ 、で50\%，次に70\%とする。夫 々の時の uv/vis spec. を求め，50名に拈りる2ケの ピーク $\lambda_{1}$ と $\lambda_{2}$ の波長及び $\mathrm{E}_{1} / \mathrm{E}_{2}$ を計算する。表 1 の項 目を夫々の試料についで表 2 にまめる。図 4 は標準上 なるCochineal, Lac dye, Kermesについて上記值を示 したものである。

他に薄篔クロマト(t. l. c.と略す)では cellulose acetate plate 上に展開剂よしてTHF：EtAC: $\mathrm{H}_{2} \mathrm{O}=36$

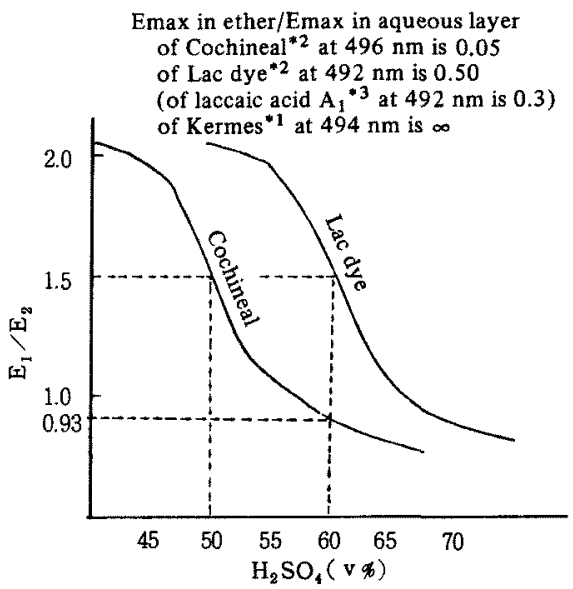

図4 屁虫色素の同定法

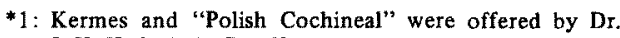
J. H. Hofenk-de Graaff.

*2: From $100 \mathrm{mgs}$ of Cochineal, $20 \mathrm{mgs}$ of dyestuff were extracted and crystallished with carbon tetrachloride (m. p. $\left.<250^{\circ} \mathrm{C}(\mathrm{dec})\right) . \quad\left(\varepsilon\right.$ in $\left.\mathrm{H}_{2} \mathrm{O}\right)$ is about $2.6 \times 10^{3}$ at $500 \mathrm{~nm}$ ).

From $100 \mathrm{mg}$ of Lac dye, $38 \mathrm{mgs}$ of dyestuff were extracted (m. p. $<220 \mathrm{C}(\mathrm{dec}))$

*3: Laccaic acid Al was offered by Prof. K. Schofield.

表 1 昆虫色素を使用したサンプルのデータのまとめ方

\begin{tabular}{|c|c|c|c|}
\hline & $\begin{array}{l}\text { Salor } 16 \mathrm{Gul} \\
\text { (grey-red) }\end{array}$ & $\begin{array}{l}\text { Salor Long } \\
\text { (blue-red) }\end{array}$ & $\begin{array}{l}\text { Salor Saryg } \\
3 \text { Gul (silk) }\end{array}$ \\
\hline $\begin{array}{l}\lambda_{\max } \text { in } 9 \% \\
\mathrm{H}_{2} \mathrm{SO}_{4}\end{array}$ & $490 \mathrm{~nm}$ & 492 & 496 \\
\hline $\mathrm{E}_{\mathrm{Et}_{2} \mathrm{O}} / \mathrm{E}_{\mathrm{aq}}$ & & & \\
\hline in $9 \% \mathrm{H}_{2} \mathrm{SO}_{4}$ & 0.49 & 0.47 & 0.11 \\
\hline$\lambda_{1}$ in $50 \% \mathrm{H}_{2} \mathrm{SO}_{4}$ & 503 & 502 & 510 \\
\hline$\lambda_{2}$ in $50 \% \mathrm{H}_{2} \mathrm{SO}_{4}$ & 539 & 538 & 546 \\
\hline$E_{1} / E_{2}$ & 1.1 & 1.3 & 0.9 \\
\hline$\lambda$ in $70 \% \mathrm{H}_{2} \mathrm{SO}_{4}$ & $* \underline{515}, 540,554(\mathrm{sh})$ & $* \underline{512}, 540,554(\mathrm{sh})$ & $\underline{480},{ }^{*} 506,543$ \\
\hline under u. v. & greyish & greyish & \\
\hline $\begin{array}{l}\text { Rf value on } \\
\text { t. l. c. plate }\end{array}$ & 0.8 & 0.8 & ca. 0.72 \\
\hline
\end{tabular}

=三下線分が主ピーっ 他にLac dyeについては $282 \mathrm{~nm}$, Cochineal では $276 \mathrm{~nm}$ にピークが存在するが50\%及び 9 か $\mathrm{H}_{2} \mathrm{SO}_{4}$ 中で变化せず 
表 2 Prof. Thomson 所有の Salor rugs 中の昆虫色素分析結果

\begin{tabular}{|c|c|c|c|c|c|}
\hline \multicolumn{3}{|l|}{ sample } & mgs & \multicolumn{2}{|c|}{\begin{tabular}{|c|cc}
$\begin{array}{c}\mathrm{E}_{\mathrm{Et}_{2} \mathrm{O} / \mathrm{aq}} \\
\text { in } \\
9 \% \mathrm{H}_{2} \mathrm{SO}_{4}\end{array}$ & \multicolumn{2}{c}{$\mathrm{E}_{1} / \mathrm{E}_{2}$} \\
in & $50 \% \mathrm{H}_{2} \mathrm{SO}_{4}$ & result \\
\end{tabular}} \\
\hline 1.JT Salor $3 \mathrm{Gul}$ & dark mot & wool & 1.8 & 0.10 & $507 / 543=1.0$ Cochineal $^{* *}$ \\
\hline 2.JT Salor 3Gul & grey-red & silk & 2.3 & 0.14 & $508 / 543=1.0$ Cochineal \\
\hline 3.JT Salor 3Gul & dark red & silk & 1.0 & 0.08 & $508 / 543=1.0$ Cochineal \\
\hline 4.JT Salor $16 \mathrm{Gul}$ & grey-red & wool & 3.0 & 0.49 & $503 / 539=1.2$ Lac dye \\
\hline 5.JT Salor $16 \mathrm{Gul}$ & dark red & silk & 1.3 & 0.06 & $508 / 544=1.0$ Cochineal \\
\hline 6.JT Salor Long & blue-red & wool & 1.3 & 0.47 & $508 / 540=1.3 \mathrm{Lac}$ dye \\
\hline 7.JT Salor Long & red & silk & 0.4 & 0.07 & $508 / 544=0.9$ Cochineal \\
\hline 8.JT Salor Long & blue-red & silk & 1.4 & 0.08 & $508 / 544=0.9$ Cochineal \\
\hline 9.JT Saryq 20Gul & dark red & silk & 0.3 & 0.06 & $508 / 544=1.0$ Cochineal \\
\hline $\begin{array}{l}\text { 10.JT } \Psi \text { Salor } \\
\text { Saryq } 3 \mathrm{Gul}\end{array}$ & dark red & silk & 2.5 & 0.11 & $510 / 546=0.9$ Cochineal \\
\hline $\begin{array}{r}\text { 11.JT Saryq- } \Psi \\
\text { Salor 6Gul }\end{array}$ & dark red & silk & 1.3 & 0.08 & $508 / 544=0.9$ Cochineal \\
\hline $\begin{array}{l}\text { 12.JT Star } \\
\text { Arabatchi }\end{array}$ & dark red & silk & 2.2 & 0.01 & $508 / 544=0.9$ Cochineal \\
\hline
\end{tabular}

* ; at 496nm for Cochineal and at $492 \mathrm{~nm}$ for Lac dye

**; probably. Madder was found mixed with Cochineal

: 6:45を使うと $\mathrm{R}_{\mathrm{f}}$ 值 Kermes 0.2 0.3. Lac dye 0.4 〜 0.6. Cochineal 0.9であり, Cochinealは violet, $365 \mathrm{~nm} \mathrm{uv}$ 光下では蛍光した（以下 $\mathrm{fl}$.と略す） red を 呈すので，他二者とは区別出来る。学光分光計で 255 又 は $365 \mathrm{~nm}$ を抽出液に照射すると $587,425(\mathrm{sh})$ となり

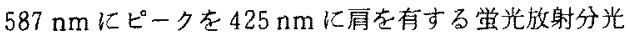
を得る。又虽光の極大波曼 $587 \mathrm{~nm}$ に打ける励起分光の 極大仕 490，445 nmである(下線が主ピーク)。Lac dye にては営光が非常に弱い(以下，ピーク，肩は上記表示 法をとる)。

\section{Madder}

redには1.で报った scale insect dyeより仏沉に使わ れたあのとして Madder（茜し訳されている）がある。 Prof.W.C. Whiting が所蔵している $1.3 \times 4.5 \mathrm{~m}$ の細長 い，粗い花柄のStair Kurd \&， ₹のred バラッキがあるため他の色共々分析することしする。

Persia 西部の Kurd 族は一説化は故䐚索持た部族で あったと調われているが Van Lake 辺りを中心として
移動を繰り返していた栐だ。これから述べる分析結果か ら，彼らが可成り原始的な独自の染色法を保存していた 一方で，移動の過程で技術の進んだ部族上の出合いによ り染色法又は染色糸を入手していたらしいことが分る。

Madder は地域により種により，又土地質，樹令，採 集後の乾燥状態により主成分色素及びその量が異なる場 合があるが，主に alizarin, purpurin（茜は pseudo purpurin)である。これらはt.1.c.でよく分離確認される。 purpurin と alizarin が主成分の場合，その比をuv/vis spec.より簡単に求める万法を略述する。

試料のうち redのみについてその結果を説明する。1. D t.l.c. 泣で便宜上後述の quercetin $0 \mathrm{R}_{\mathrm{f}}$ 值在 1.0 とし た場合の夫々の色素の $\mathrm{R}_{\mathrm{f}}$ 値を $\mathrm{R}_{\mathrm{q}}$ として示す。標準 alizarin, purpurin $の \mathrm{R}_{\mathrm{q}}$ は 0.91 £0.65である。とれらの スポットに $\mathrm{AlCl}_{3}$ 又は $\mathrm{NaOMe} の \mathrm{MeOH}$ 溶液をスプレ 一し，その色変化を観察すると表 3 となる。表中 $(V u v)$ とは $365 \mathrm{~nm}$ のブラックライト下で兒た時の色を示す。 蛍光分光をとると表 4 となり，uv/vis spec. は图 5 と なり検舅線を図式化しておくと purpurin/alizarin の比

表 3 Madder 含有の色素主成分の $\mathrm{R}_{\mathrm{q}}$ 值

(Rqは quercetin $\sigma R_{\mathrm{f}}$ 亿刘する相対的 $\mathrm{R}_{\mathrm{f}}$ 值)

$\mathrm{Rq}$ (=Rf/'Rf' of quercetin) on t. 1. c. cellulose acetate plate (THF: ErAc: $\mathrm{H}_{2} \mathrm{O}=36: 6: 45$ )

\begin{tabular}{|c|c|c|c|c|c|c|c|}
\hline & $\mathrm{Rq}$ & daylight & uv (365) & $\mathrm{AlCl}_{3}$ & $\mathrm{AlCl}_{3} / \mathrm{uv}$ & $\mathrm{NaOMe}$ & $\mathrm{NaOMe} / \mathrm{uv}$ \\
\hline purpurin & 0.65 & yellow & fl. red & pink & fl. orange & pink & fl. pink \\
\hline & 0.91 & orange & dark red & $\begin{array}{l}\text { pink- } \\
\text { brown }\end{array}$ & $\begin{array}{l}\text { dark } \\
\text { violet }\end{array}$ & violet & dark violet \\
\hline$\Psi$-purpurin & 1.21 & orange & fl. red & pink & fl. pink & pink & fl. pink \\
\hline
\end{tabular}


表 4 蛍光分光スペタトル

\begin{tabular}{|l|c|r|l|}
\hline \multirow{2}{*}{ sample } & \multicolumn{2}{|c|}{ when excited at } & when emitted \\
& $255 \mathrm{~nm}$ & $365 \mathrm{~nm}$ & at 560nm \\
\hline pink & 380,560 & 560 & $340,490^{*}$ \\
Flower red-brown & 380,560 & 425,560 & 340,490 \\
Border ground red-brown & 380,560 & 425,560 & 340,490 \\
Maroon brown & $370-, 560$ & 425,560 & 340,495 \\
purpurin & 380 & & \\
alizarin*2 & 560 & 560 & 340,490 \\
\hline
\end{tabular}

* : $\mathrm{nm}$

$* 2$ : Spectrum of Alizarin is very weak.

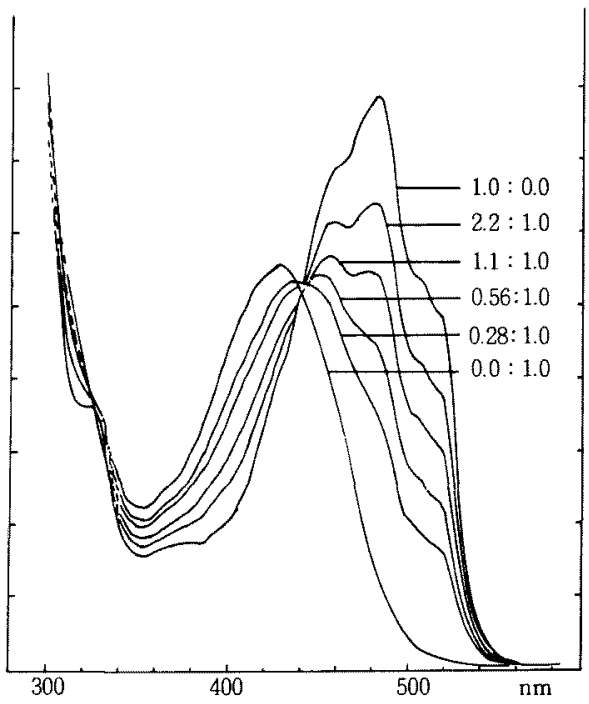

図 5 madder 中のプルプリン:アリザリン比 の変化 (エーテル中)

に上る変化が求められる。これら標準値 に対し試料についてチェックすると， "pink","flowers: red-brown" "border ground" "maroon” が Madderである ことが尔かる。 $\mathrm{R}_{\mathrm{q}}$ は 0.91 と0.65，蛍光 分光は表 4, uv/vis spec. は図6，ま之 めると表 5 となる。表 5 中 $4 \times 10^{-9}$ 等は mol.of dye/mg of pileの值者す。 $\mathrm{p} / \mathrm{a}$ 比のバラッキより Madder 使用 して red の範囲を広げる染色技術を有し ていたか，乙心様な染色系を入手してい たこと加推察出来る。媒染剤として使用 されたであろう $\mathrm{Fe}$ 及び $\mathrm{Al} の$ 量を原子吸
光で測定すると表 6 となり特飞"'maroon"のFe の值加高い。

更に質量分析（以下 $\mathrm{ms}$ 之略す）につ ては，ペーパークロマト (pc)にて带状 に分離して分析するよ，親ピークを $\mathrm{m} / \mathrm{e}$ 240 上 256 に有し alizarin, purpurin 独 特のパスを通って開裂していく。てれと 後述の yellow $の \mathrm{~ms}$ につての解説は 䋏数の関係上次の機会にしたい。 yellow については後述するが， t.lc のみの結果示すと麦 7 となる。 $\mathrm{Rq}=$ $=0.77$ と 0.86 亿相当する部分をガスク 口（gc）で分離しmsにかけると rhamnetinと rhamnazinと分加り，これはPersian Berriesで あるう。

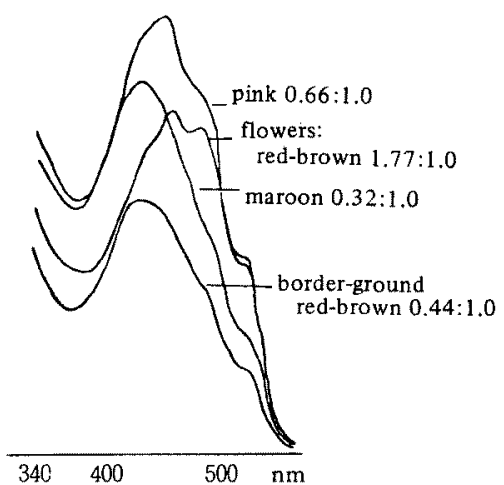

図 6 Prof. Whiting所有“Stair Kurd”使用されている madder 中のプルプリン：アリザリン比
表 5 Prof. Whiting 所有のStair Kurdの色素方析結果

\begin{tabular}{|l|l|}
\hline \multicolumn{1}{|c|}{ Sample } & \multicolumn{1}{|c|}{ Result } \\
\hline Pink & Madder $(\mathrm{p} / \mathrm{a}=0.66)\left(4 \times 10^{-9}\right)+$ yellow \\
Flowers:red-brown & Madder $(\mathrm{p} / \mathrm{a}=1.77)\left(11 \times 10^{-9}\right)+$ yellow \\
Border ground & Madder $(\mathrm{p} / \mathrm{a}=0.44)\left(12 \times 10^{-9}\right)$ \\
Maroon & Madder $(\mathrm{p} / \mathrm{a}=0.32)\left(8.2 \times 10^{-9}\right)+$ yellow \\
Mid-blue & Indigo \\
Dark blue & Indigo \\
Blue-green & Indigo +yellow \\
Light ivory & None \\
Ivory (warp) & Yellow \\
Light yellow & Yellow \\
Light yellow-green & Indigo +yellow \\
Black & None \\
\hline
\end{tabular}


表 6 Prof. Whiting 所有Stair Kurdのパイルの原子吸光份析値 $\begin{array}{cc}\operatorname{mol} \times 10^{-9} \text { per } \mathrm{mg} & \operatorname{mol} \times 10^{-9} \text { per mg } \\ \mathrm{Fe} & \mathrm{Al}\end{array}$

maroon

border ground, red-brown

40.3

4.3

2.7

6.3

flowers, red-brown

表 7 Prof. Whiting 所有 Stair Kurdの色絭 の薄層クロマトグラム

t. 1. c. (THF)

"light yellow"

$\mathrm{Rq}$ (=Rf/Rf of quercetin)

Persian Berries

$$
0.65,0.77,0.86,0.98
$$

$0.63,0.74,0.86,1.00$

\section{Yellow}

ワシントンの緎維博物館( the Textile Museum)加ら， Prof. M. Beattie 通じて届いたKirman 0 vase carpet

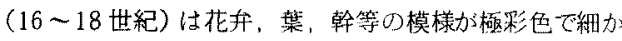
に織り这まれている。この中の1枚は絹で織られ，かつ 最类美術的に優れているが，一般的に偽造品之考えられ Vase Forgery しも呼ばれている。これらvase carpets は Kirmanにより製造されたよなって书り正しいである うが，印度の影響がデザイン的にあ予想され，それが染 料の上てどう琴われるか眶味あるとしろである。結果を 先に述へると印度からこの地方に持ち込まれたよ考えら れるLacdyeで redが構成されている。ただ1点Vase
20.3

18.9

25.8

21.3
ForgeryのみはCochineal在使用している か，合成色美が持ち込ま机る以前に Cochineal 加望入されたととは充分考えられ， その後この地方で織られたものと䧴察され 30

次奉際の分析では, 先ずyellowsにつ

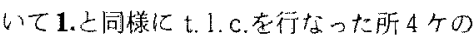

珙なるyellows が見つかり，標準データ上比较するとYI 〜YN となる。t.1.c.及びuv/vis spec.の結果老次真 の表 9 に示す。表 80 YI は Purging Buckthorn, YIIは Weld，YNはSophora japonica 等が考えられる。液

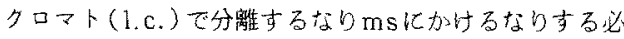
要があるが，今回は量的に難しかったので見送った。

redは次頁の表 10 となり Vase Forgery（TMR 33.6. 9.)のみCochineal 使用している。 Madderは yellow よindigoとのコンビネーションで使われている。 indigoは t.l.c. , uv/vis spec, ms で留单に判定され 得る。59件の陚料全体の結果は載甘られない口で色上 数についてのみ表11とする。

\section{4. 合成染料 -1}

所有者 Mr. R. Purdonが Tekke-B 上呼ぶrugは，彼 が主張する19世紀前半のあのとは考えられない色であ るとし、所有者汃分析を希望したことに上り合成染料を 使用しているかどうかを判定することとなった。

Tekkeは中央アジアで最も勢力のある部族でその rug DGul D一例在図7亿示或。多角形常に4 分化し，己

表 8 the Textile Museum $\emptyset$ Kirman vase carpets に使用されている yellow 等色素

$$
\begin{aligned}
& \text { Y I = mainly Kaempherol, } \\
& \text { Y II = Luteolin etc., } \\
& \text { Y III = unkown to us, } \\
& \text { Y IV = mainly Quercetin and Kaempherol }
\end{aligned}
$$

\begin{tabular}{|c|c|c|c|c|c|c|c|c|c|}
\hline & \multirow{2}{*}{$\begin{array}{l}\lambda_{\max } \text { in } \\
\mathrm{Et}_{2} \mathrm{O}\end{array}$} & \multicolumn{3}{|c|}{- t. 1.c. $-(\mathrm{THF})^{* 1}$} & \multirow{2}{*}{$\mathrm{AlCl}_{3} / \mathrm{uv}$} & \multirow{2}{*}{$\mathrm{NaOMe}$} & \multirow{2}{*}{$\mathrm{NaOMe} / \mathrm{uv}$} & \multicolumn{2}{|c|}{$(\mathrm{TBA})(\mathrm{AcOH})$} \\
\hline & & $\mathrm{Rq}^{* 2}$ daylight & $u v * 3$ & $\mathrm{AlCl}_{3} / \mathrm{uv}$ & & & & Rf & $\mathrm{Rf}$ \\
\hline$\overline{\mathrm{YI}}$ & $364 \mathrm{~nm}$ & $0.92^{* 4}$ none & none & e yellow & fl. greenish yellow & yellow & llow & 0.90 & 0.02 \\
\hline YII & $360 \mathrm{~nm}$ & 1.12 none & none & yellow & fl. dar & yell & dark & 0.95 & 0.03 \\
\hline YIII & none & $1.23^{* 5}$ none & none & none & bluish & nor & & none & none \\
\hline YIV & $366 \mathrm{~nm}$ & $\begin{array}{l}1.00 \text { none } \\
0.92\end{array}$ & none & yellow & fl. greenish yellow & dark yellow & brownish yellow & 0.90 & 0.03 \\
\hline
\end{tabular}

*1: (THF); plate=cellulose acetate, eluent $=T H F:$ Et Ac: $\mathrm{H}_{2} \mathrm{O}(36: 6: 45$ vol\% $)$

(TBA); " =cellulose, , =t-BuOH: $\mathrm{AcOH}: \mathrm{H}_{2} \mathrm{O}(3: 1: 1)$

(AcOH); " =cellulose , " $=15 \% \mathrm{AcOH}$

*2: $\mathrm{Rq}=\mathrm{Rf} /$ ' $\mathrm{Rf}$ ' of quercetin

*3: uv=under a $365 \mathrm{~nm}$ uv lamp

*4; accompanied by Rq's of $1.08,0.92,0.74$, and 0.68

*5 : mixture of two; either can be the main component 
表 9 the Textile Museum $\odot$ Kirman vase carpets 中の昆虫色菜尔析結果

\begin{tabular}{|c|c|c|c|c|}
\hline \multicolumn{2}{|c|}{ sample } & \multirow{2}{*}{$\begin{array}{l}\mathrm{EEt}_{2} \mathrm{O} \\
\text { Eaq } \\
\text { at } 494 \mathrm{~nm} \\
0.59\end{array}$} & \multirow{2}{*}{$\begin{array}{l}\frac{\mathrm{E}_{600} \mathrm{~nm}}{\mathrm{E}_{840} \mathrm{~nm}} \\
\text { in } \mathrm{H}_{2} \mathrm{SO}_{4} \\
1.0\end{array}$} & \multirow{2}{*}{$\frac{\text { result }}{\mathrm{Lac}}$} \\
\hline TMI 969.11. 3 & deep pink & & & \\
\hline TMR 33.6.8. & $\begin{array}{l}\text { crimson } \\
\text { salmon } \\
\text { red }\end{array}$ & $\begin{array}{l}0.73 \\
0.64 \\
0.58\end{array}$ & $\begin{array}{l}1.0 \\
1.0 \\
1.0\end{array}$ & $\begin{array}{l}\text { Lac } \\
\text { Lac } \\
\text { Lac }\end{array}$ \\
\hline TMR 33.6.6 & crimson & 0.58 & 1.0 & $\mathrm{Lac}$ \\
\hline TMR 33.6 .4 & $\begin{array}{l}\text { red } \\
\text { pink }\end{array}$ & $\begin{array}{l}0.74 \\
0.60\end{array}$ & $\begin{array}{l}1.0 \\
1.0\end{array}$ & $\begin{array}{l}\mathrm{Lac} \\
\mathrm{Lac}\end{array}$ \\
\hline TMI 969.11.6 & red & 0.61 & 1.0 & $\mathrm{Lac}$ \\
\hline TMR 33.6.3 & $\begin{array}{l}\text { red } \\
\text { pink }\end{array}$ & $\begin{array}{l}0.50 \\
0.50\end{array}$ & $\begin{array}{l}1.0 \\
1.0\end{array}$ & $\begin{array}{l}\mathrm{Lac} \\
\mathrm{Lac}\end{array}$ \\
\hline TMR 33.6.1 & red & 0.40 & 1.0 & $\mathrm{Lac}$ \\
\hline TMR 33.6.5 & red & 0.70 & 1.0 & $\mathrm{Lac}$ \\
\hline TMR 33.3 .1 & red & 0.46 & 1.0 & $\mathrm{Lac}$ \\
\hline TMR 33.6 .2 & purple red & 0.58 & 1.0 & $\mathrm{Lac}$ \\
\hline $\begin{array}{l}\text { TMR 33.6.10 } \\
\text { GE } 5\end{array}$ & purple red & 0.47 & 1.0 & $\mathrm{Lac}$ \\
\hline TMR 33.6.9 & rose red & ca 0.0 & $0.9^{*}$ & Cochineal \\
\hline
\end{tabular}

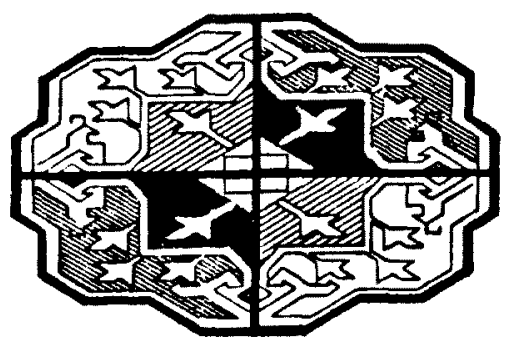

図 7 Tekke Gul $の$ 一例

この試料はパイルの上方が色抜きか退色 のためか着色度が低い。Cochineal, Indigo, Madderについては1.〜3.で述べた方 法で確認した。残った 1 色“orange”につ いて，抽出液を cellulose plate上 $50 \% \mathrm{di}$ gol $に$ pH 4.0 のbufferを $1 \%$ 添加した溶 液で電気泳動で展開させると一 $\mathrm{SO}_{3}^{-}$基 1 ケ 有する 'yellow'が主成分と一 $\mathrm{SO}_{8}^{-}$基 2 ケ を有する'pink'の副成分とに分れた。先ず 'yellow'について uv/vis spec. をとると

の中に犬か馬をあしらった構図であり，全般的に濃い赤 をバックに白と緑又は青を配色したものが多い。19世 紀央前後のものが可成り最近迄安価に取引きされていた が、現在では一般の関心が高くなったためか急激に值上 りしている。
表 11 となる。酼酸中でのシフト $\Delta \mathrm{Ha}=45 \mathrm{~nm}$ は集めて あるデータより，4'-sulphonic arylazo-naphthol 又は dinaphthalene dyes 亿特徽的である。488nm のビー ムでよった表 11 中の其鳴ラマンスペクトル（rrs）で波 数 $\left(\mathrm{cm}^{-1}\right)$ 群 $1232(100), 1340(48), 1392(66), 1505$

表 10 The Textile Museum の Kirman vase carpets K使用されている色素の分析結果(まとめ)

\begin{tabular}{|c|c|c|c|c|c|c|c|c|c|c|c|}
\hline sample & \multicolumn{4}{|c|}{ Madder ${ }^{*}$} & \multicolumn{4}{|c|}{ Yellow*2 } & $\begin{array}{c}\text { Insect dye } \\
\text { Lac Cochineal }\end{array}$ & Indigo & Nos of sample \\
\hline TMI 969.11 .3 & & 0 & & & 0 & & & & 0 & & 2 \\
\hline TMR 33. 6.8. & & 0 & & & 0 & & & & O & 0 & 6 \\
\hline TMR 33. 6.6 . & & 0 & & & 0 & & & & 0 & & 4 \\
\hline TMR 33. 6.4. & & 0 & 0 & & $\mathrm{O}$ & 0 & & & $\mathrm{O}$ & 0 & 6 \\
\hline TMI 969.11 .6 & & & $\mathrm{O}$ & & & 0 & & & 0 & 0 & 5 \\
\hline TMR 33. 6. 3. & & 0 & 0 & & 0 & 0 & & & 0 & & 8 \\
\hline TMR 33. 6.1. & & $\mathrm{O}^{* 3}$ & & & & $\mathrm{O}$ & & $\bigcirc$ & $\mathrm{O}$ & & 3 \\
\hline TMR 33.6. 5. & & & $\mathrm{O}$ & 0 & 0 & & & 0 & $\mathrm{O}$ & 0 & 5 \\
\hline FI11. 55.65 .26 & & $0^{* 4}$ & & & & & 0 & & & & 1 \\
\hline TMR 33.3.1 & & & & 0 & & 0 & 0 & & 0 & $\mathrm{O}$ & 5 \\
\hline TMR 33.6.2. & 0 & & & 0 & 0 & 0 & & & 0 & 0 & 4 \\
\hline $\begin{array}{l}1 M E \\
G E 5\end{array}$ & 0 & & & & & 0 & & & 0 & 0 & 6 \\
\hline TMR 33. 6.9 & 0 & & & & & & & 0 & 0 & 0 & 4 \\
\hline
\end{tabular}

* : Ratio of purpurin to alizarin in the Madder

*2: YI=mainly kaempherol, YII=luteolin etc., YIII=unknown,

YIV=kaempherol, qurcetin, etc.,

$* 3$ : probably

*4: trace 
表 11 Mr. Purdon 所有のTekke-B中“yellow”部分の分析結果

\begin{tabular}{|c|c|c|c|c|c|c|c|c|c|c|c|}
\hline$\lambda_{\max }(\mathrm{nm})$ & $\mathrm{H}_{2} \mathrm{O}$ & $\mathrm{BuOH}$ & $2 \mathrm{~N}^{-}$ & $\mathrm{NaOH}$ & Buffer & ${ }^{*} \mathrm{Cu}^{+}$ & $80 \%$ & $\mathrm{H}_{2} \mathrm{SO}_{4}$ & $\Delta \mathrm{Ha}$ & $\Delta \mathrm{Hb}$ & $\Delta \mathrm{H}_{\mathrm{Cu}^{++}}$ \\
\hline "yellow" & 485 & 488 & 448 & $(520)$ & 488 & 478 & & $554)$ & 45 & -37 & -7 \\
\hline Orange II & 486 & 487 & 459 & (507) & 487 & 480 & 532 & (552) & 46 & -27 & -6 \\
\hline \multicolumn{12}{|c|}{$\begin{array}{l}{ }^{*} \mathrm{pH} 7.0 \\
\text {-resonance Raman spectra- }\end{array}$} \\
\hline \multirow{2}{*}{ "yellow" } & $\nu$ & 935 & 980 & 990 & 1002 & 1107 & 1125 & 1135 & 1148 & 1170 & 1180 \\
\hline & r. $i$. & 12 & 12 & 10 & 6 & 12 & 22 & 22 & 12 & 15 & 15 \\
\hline$\nu$ & 1240 & 1258 & 1270 & 1285 & 1295 & 1317 & 1345 & 1365 & 1390 & 1440 & 1465 \\
\hline r. i. & 100 & 45 & 22 & 22 & 15 & 12 & 38 & 48 & 30 & 20 & 30 \\
\hline$\nu$ & 1500 & 1515 & 1555 & 1595 & 1605 & & & & & & \\
\hline r. i. & 63 & 50 & 12 & 66 & 72 & & & & & & \\
\hline \multirow{2}{*}{ Orange II } & $\nu$ & 992 & 1010 & 1105 & 1125 & 1190 & 1232 & 1265 & 1308 & 1340 & \\
\hline & r. i. & 39 & 20 & 46 & 14 & 48 & 100 & 43 & 14 & 48 & \\
\hline$\nu$ & 1392 & 1422 & 1457 & 1485 & 1505 & 1557 & 1601 & & & & \\
\hline r. i. & 66 & 34 & 23 & 43 & 52 & 16 & 83 & & & & \\
\hline
\end{tabular}

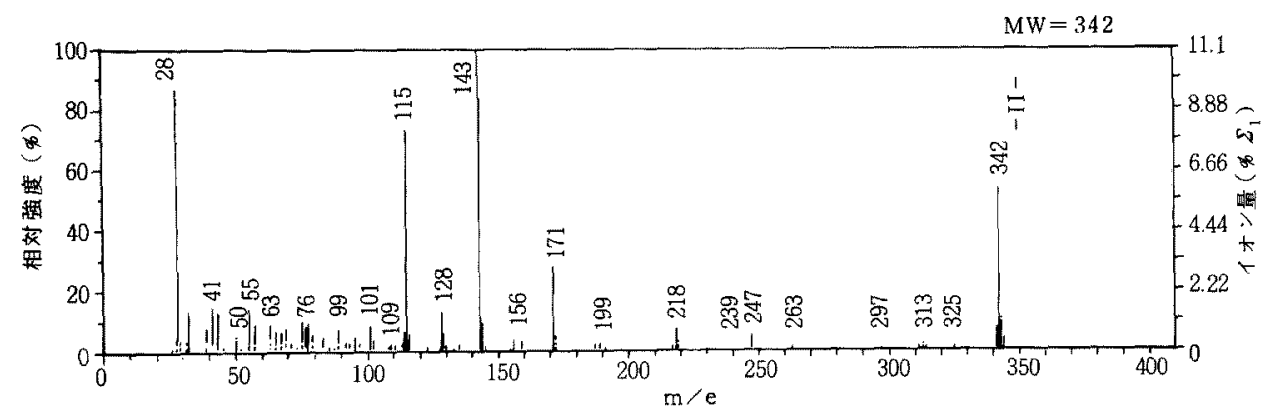

四8 TEKKE Bの“yellow”のマススペクトル

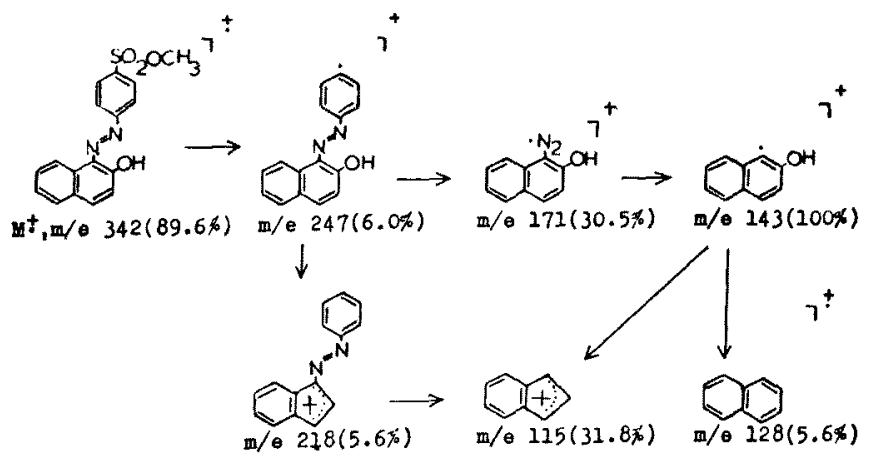

因 9 ×チル化 Orange II マススペクトル

(52)は arylazo-naphtholに一般に兒られるので Orange Iにと比较すると全く一致し，'yellow'は Orange II と同 定される。確認のため試料を sodium dithionite で還元

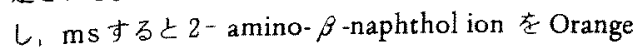

II同㴍に基準ビークとして示す。 次化第 2 成㸮'pink'は極微量でを のままでは uv/vis spec.より混 合物らしく，加完全分離加電気 泳動では出来ないので， tetrabutylammonium acetate 2 methyl fluorosulphonate $\checkmark$ micro cellulose glass plate(展 開剤n-hexane: dichloromethane $=2: 1$ )で t.l.c.すると $\mathrm{R}_{\mathrm{f}}=0.53$ の主成分と，更橵量の $\mathrm{Rf}_{\mathrm{f}}=0.41$ が存在する。 $R_{f}=0.520$ uv $/$ vis spec. は次項比む出て来る Ponceau $2 \mathrm{R} の \mathrm{Me}$ 化したb のと一致する。一方前記'yellow' 局様䎲 Me 化し ms すると図8となり，各フラグメントを帰属させると図 9 の様汇 Orange II 上全く同一の結果を得る。この結果を 


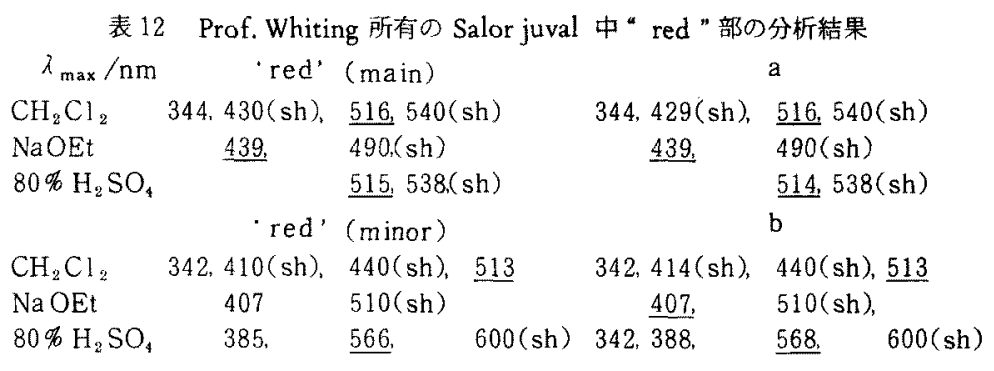

いる。又、cでは前述の uv/vis spec. の結果 と合わず，dなら a比 ついて述へた様に m/ e 273 の 4 -methoxysulphonyl indenyl sulphinic acid cation を生ずる筈である。所 が (minor) $0 \mathrm{~ms}$ kは 所有者は気持ちよく認めた上でそれなりの価徝をとの rugに再度見い出したとのととである。

\section{5. 合成染料 -2}

Prof. M. C. Whiting の所有しているもので Salor juvalと呼ばれているが，構造什明らかに Tekkeのわの である。4.では合成染料の一例として Orange IIを uv/ vis spec. 及び r.r.s. により同定する方法を上げたか， ここではmsを使って説明する。 Indigo とCochineal は前述迄の方法で同定したか，残っだ red”は t.1.c. と uv/vis spec.上り- $\mathrm{SO}_{3}$ 基を 1 个と 2 个持った azo dyes と推定される。そこで4.の Orange II 同様に Me 化し，再度 4.で述べた t.l.c. するとuv/vis spec.より主 成分 'red'は methoxysulphonyl 基老 2 ケ，第 2 成分 “orange’は1ケ有する染料であるこ上が分る。'red’を t.l.c. で再度分離し， $\mathrm{CH}_{2} \mathrm{Cl}_{2} ， \mathrm{NaOEt}$ 存在下. $80 \%$ $\mathrm{H}_{2} \mathrm{SO}_{4}$ 中での夫々の uv/vis spec. 老求めると表 12 と なる。標準品で集録したデータ上り $\Delta \mathrm{Ha}=515-516=$ 1. $\Delta \mathrm{Hb}=439-516=-77 \mathrm{~nm}$ は $\mathrm{Me}$ 化以前が置換 phenyl azo- $\beta$-naphthol- 3,6-又は 6,8 -disulphonic acid $, \Delta \mathrm{Ha}=53, \Delta \mathrm{Hb}=-106$ \& dinaphthalene disulphonic acidであるととを予想させる。これら‘red. (main)上 (minor)の二者学的すると，(main)上り図 11を得， $\mathrm{M}^{\dagger} ， \mathrm{~m} / \mathrm{e} 464$ を親ピークに3つの重要なパス を図10の様に通るととより図 12 の Ponceau 2R(=a) に相当する。図 10 で m/e 273，4-methoxysulphonyl -indenyl sulphinic acid cation 33,6 -dimethoxysulphonyl- $\beta$-naphthol group (Me 化R酸) 亿特徽的であ る。a の夫々のフラグメントより図13老得る。(minor) は $\mathrm{M}^{+}, \mathrm{m} / \mathrm{e} 486$ 親ピーク $\mathrm{m} / \mathrm{e} 391$ 亿強いピーク $\left(\mathrm{M}^{+}-\mathrm{SO}_{2} \cdot \mathrm{OCH}_{3}\right)$, naphthylamine ion, m/e 143 (100\%), naphthyl ion m/e 127 在持方図 12 中 b と同 定される。何故なら 6.8-dimethonysulphonyl- $\beta$-naphthol はカサ高い 8-methoxysulphonyl group 在脱 離し, 強い $\mathrm{M}^{\dagger}-\mathrm{SO}_{2} \mathrm{OCH}_{8}$, 又は $\mathrm{M}^{\dagger}-\mathrm{SO}_{2} \mathrm{OCH}_{2}$ ion を示し，かつdiazocomponent側に安定したフラグメン 卜を示し基準ピークを $\mathrm{m} / \mathrm{e} 143$ 亿有するととが分って その值が見られない。依って'red'はa上bの混合物で ある。他方“orange’について t.l.c.でうまく分踓出来 ないため，Me化したものをそのままmL，フラグメ ントを注意深く分けながら帰属させた結果図 $140 \mathrm{e}$ 上 f の湿合と同定された。全体として使用されていた染料 比少求加ると $\mathrm{a}: \mathrm{b}: \mathrm{e}: \mathrm{f}=86: 34: 10: 4 ;(\mathrm{a}+\mathrm{e}) /(\mathrm{b}$ $+\mathrm{f})=96 / 38 \div 2.5$ 之なり，Me 化の収率を考慮して $5.5 \times 10^{-8} \mathrm{~mol}$ of dye $/ \mathrm{mg}$ of pile $=2.5 \mathrm{~g} / \mathrm{kg}$ of pile の染料が染色されていたとととなる。これら鼬合物は(i) $m$-xylidine 無意識K $\beta$-naphthol - 6 - sulphonic acid $\angle \beta$-naphthol-3, 6-disulphonic acid $と の$ 混合物 とカップリング, (ii) 1-naphthyl amineを $\beta$-naph thol-6,8-disulphonic acid $\measuredangle$ monosulphonic acid $と$ をカップリングし，(i)上(ii)を混合して染色に使用したと 推定される。乙の样な中間体が反応混合物として使われ るケース怙可成りあり，又㬰際混合の種類も分らなかっ たであろうし，分離する必要性むなかったであるう。

以上じゅうたん使用されている天然及で合成の染料 につき1.〜5.で実例を.上げてその分析方法を述へて来た が，当然のととなからら，他の染織物への応用当即坐儿行 なえる。例えばアレキサンダー大王により大虑殺（BC

1.
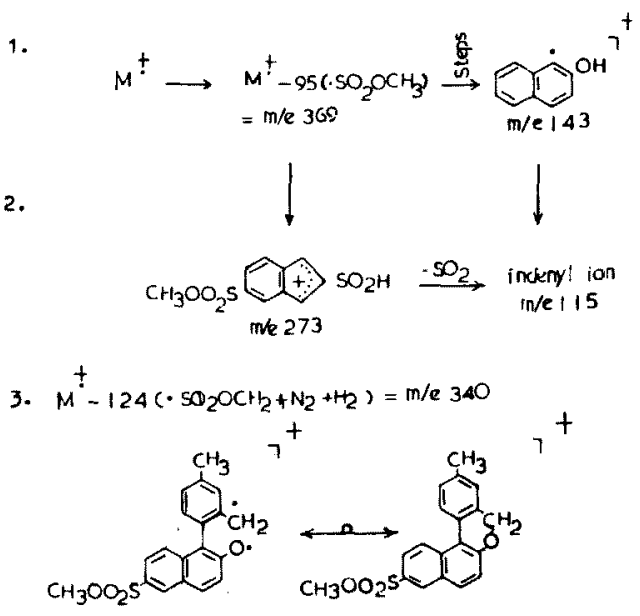

因 $10 \times$ ×ル化Ponceau 2Rのマススペクトルの特徵 


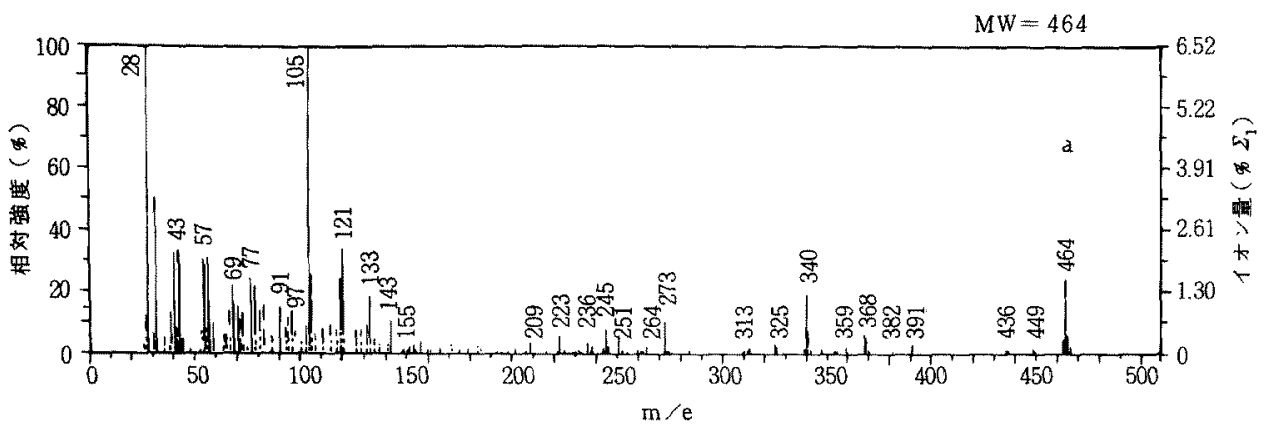

図 11 SALOR JUVAL-2の“red"中'red'(main) のマススベクトル

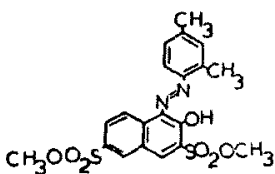

a

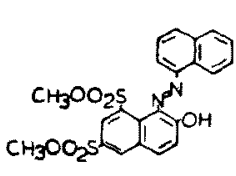

b

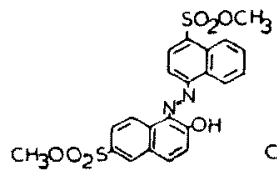

图122ケのスルフォン基を有する代表的アゾ色素のメチル化物

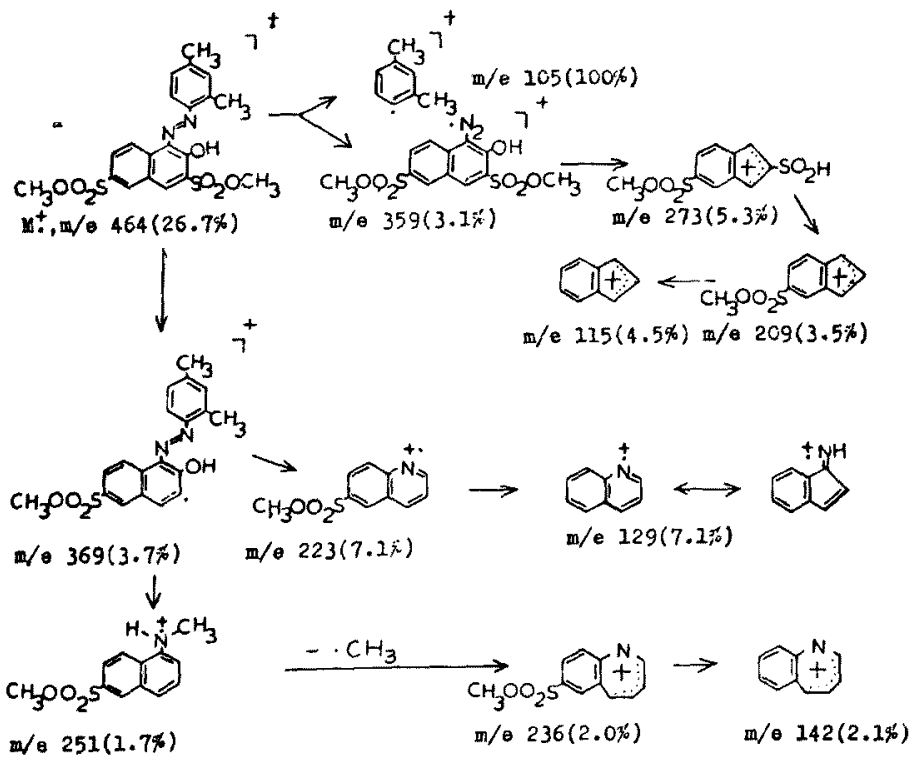

困13メチル化 Ponceau 2Rのマススペクトルパス

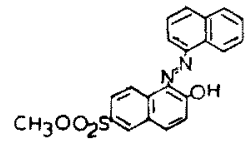

e $M^{t}, \mathbf{m} / \mathrm{e} 392$<smiles>COO[SH](=O)(OC)c1ccc2c(N=C(O)c3ccc(C)cc3)cccc2c1</smiles>

f: $M^{t}, m / e 370$

図 14 Prof. Whiting 所有の Salor juval 中" red" より行離しだorange” 部分の湿合色素

331）されたSomariaの民の隠札家 家よなったエルサレム近くのシェリコ のWadi ed Daliyeh洞穴加らの発堀 品中の染織物に数種の色素が確認さ れた等々である。

最後にこれらじ由うたんが如何に 保存されているか心つて一言触れ ると，本文中任出て来る Univ. of Bristol Prof. M. C. Whiting t心 じめとするじゅうたんに造詣の澡い 熱心な collectorである人々の場合 は特別であるが，一般家庭で所有さ れている場合は注とんどが床に僌か れているか，壁にかけるか，納屋に しまい込まれているかである。しの 場合所有者がある種の洒犆を認めて いれば可成り大事に扱われるが，を 
うでない上極く短期間に污され傷つけられ再生不能とな る。一方博物館，美術館ではどうかというと，保存之 研究者への便とを別々に考え，特にその調整かうまくい っているのが, the Berlin State Museum(西独)であ 乃j。London $\Phi$ the Victoria and Albert Museum 研究者用のためには寛容であり，Vienna の the Aust rian Museum for Applied Arts $や$ Paris $の$ the Musie des Arts Decoratifs, the Berlin State Museum (東独) 等も同様である。欧州では博物館の美術工芸品等を保存 する佸動が盛んで，染織物についても活発汇行なわれつ つある。
ここに述へた内容は “Micro-scale Identification of Dyes in Textiles of Art-Historical Importances" $と い$ うテーマで 1973 年〜 75 年にかけ the Univ. of Bristol, Englandで著者が行なった仕事の一部を抜萃したる のである。特に数の多いyellows とをれらを効果的に同 定する液ク口と兵量分析の組合甘等については次の機会 にしたい。実際に参考になる図表をという依頼むあった ため，乙の場には図表が多過ぎた嫌いがあるがで了解願 いたい。

(昭和 53 年 9 月 20 日受理)

\section{第 338，339回常任理事会議事録（拢粋）}

日 時：昭和 53 年 9 月 26 日(火), 10 月 24 日(火)

場 所 : 䋐維学会会議室 (338 回) - 国立教育会館第一会 議室 (339回)

出席者: 河合弘廸会長, 鈴木三男, 栗田洵，久世栄一 副会長，西田健三，池田佐害男，黒木宣彦，清 水二郎，宮坂啓象，相坂登，酒井哲也，前田 公夫，木下陸肥路，越村哲夫，物延一男，中村 正人，在竹政俊各理事，大野泰雄，砥波宏明各 監事

議事:

1. 第 11 回(昭和 53 年度)夏季セミナ一報告: 8月 23 日 (水) 25日(金)にわたって行なわれた夏季セミナーは， 講師はもちろんのとと，関係分野の参加者および実行 委貞のご尽力により，上高地の天候にも恵まれて盛会 裡に催されたととが，大野実行委員長より謝意をこめ て報告された。(参加者 285名)

2. 第 8 回緎維連合研究発表会について：11月9日(木) ～11日(土)に開催する表記連合7学会に上る研究発表 会の中間報告か行な⿰れ（特別講演 2 件. 研究発表件 数 108 件)，当日の参加人員について檢討した結果， 河合 徹実行委員長から実行委員および関係设貣の方 々から多数の参加者を勧誘していただきたい旨の依頼 があった。

3. 昭和 54 年度年次大会について：明年6月 28 日(木) 〜30日(土)03日間にわたっての年次大会は例年通り 東京・国立教育会館に求いて開催する。詳細な打合せ については実行委員会で憲議する(奏行委員長 西田 健三)

4. 第 12 回夏季セミナー開催について：開催場所，日 取について久世栄一実行委員長加ら現在候補地を各地 にわたって検討中であることが報告された。
5. そのほか：(1)日米ハワイミーティング，(可緎維学会

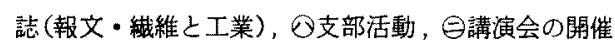
（共催・協替む含む)などについてそれぞれ報告，検討 した。

正会貫入会者（26名）

\begin{tabular}{|c|c|c|}
\hline 小川 力郎(トヨ夕自動車) & 井上 & 武久(井上プリーツ) \\
\hline 愛子 (姫路短大) & 越智 & 義治(沟山女子短大) \\
\hline 法（湖德高校） & 田原 & 健二(ワコーケミカル) \\
\hline 弥生 (京都女子大) & 井上 & 隆利(名工大) \\
\hline 寿郎 (京大·工) & 唐牛 & 勇(地川工専) \\
\hline 信也 (防衛大 - 機械) & 金子 & 憲明(日本ゼオン) \\
\hline 李 相 奎(罆南専門) & 金子 & 由美(本村寝台工業) \\
\hline 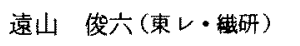 & 梶 & 查輔(京大・化研) \\
\hline 豊（東レ・織研） & 田中伊 & 都郎(東洋紡樍 - 研) \\
\hline 盛男 (チッン・技本) & 田坂 & 茂(辳工大·I) \\
\hline 克美（香川大・農） & 榎本 & 恵誉(カシュー・生産) \\
\hline 小林修三郎（諸星インキ） & 本野 & 一郎(保土谷化学) \\
\hline 日本 晴夫 (大阪合同) & 富岡 & 享( 䄉維 \\
\hline
\end{tabular}

学生会員入会社 (8 名)

\begin{tabular}{|c|c|c|c|}
\hline 寺沢 & 敬人（農工大・工） & 春日 & 澺雄(山梨大 -I) \\
\hline & 隆 (京工䄉大・緎) & 和田 & 正嗣 (山梨大 - I ) \\
\hline & 啓二(信州大・䋐) & 柴田 & 芳明(京工㵶大・院) \\
\hline & 渾 (信州大 ・ I) & 野村 & 泰好（京工緎大・院） \\
\hline
\end{tabular}

賛助会員入会（3社3口）

$\begin{array}{ll}\text { 東洋製缶グループ綜合研究所 } & 1 \square \\ \text { 有限会社アスカ電子 } & 1 \square \\ \text { 株式会社神戸製鋼所プラント本部 } & 1 \square\end{array}$

[順不同・敬称略〕 